\title{
Paresia gástrica masiva como único hallazgo diagnóstico de linitis plástica por carcinoma de células en anillo de sello
}

Massive gastric paresis as a single diagnostic finding of plastic linitis

due to single ring cell carcinoma

Aingeru Sarriugarte-Lasarte ${ }^{1}$, Ohiane Gutiérrez-Grijalba ${ }^{1}$, Irene Álvarez-Abad ${ }^{1}$ y Miguel Calle-Baraja ${ }^{1}$

Mujer de 54 años que consultó en urgencias por vómitos realizándose Rx abdominal y TC (Figura 1) donde se aprecia una gran distensión gástrica. Tras descompresión nasogástrica se realizó gastroscopia sin hallazgos de neoplasia ni obstrucción mecánica de otra causa. El estudio de biopsias aleatorias mostró infiltración por carcinoma con células en anillo de sello. Se intervino para gastrectomía total con hallazgo de linitis plástica (Figura 2). El carcinoma difuso de células en anillo de sello es un tumor cada vez más frecuente que difunde por la submucosa hasta convertirse en transmural con rapidez dando una imagen macroscópica de linitis plástica y respetando en algunas ocasiones la mucosa, por lo que es preciso un alto nivel de sospecha clínica para realizar biopsias aleatorias que llevarán al diagnóstico.
Cirugía General y Aparato Digestivo, Hospital universitario de Cruces, Barakaldo, Vizcaya, España.

Recibido el 14 de agosto de 2017 y aceptado para publicación el 30 de agosto de 2017.

Correspondencia a:

Dr. Aingeru SarriugarteLasarte

aingeru.sarriugartelasarte@ osakidetza.net

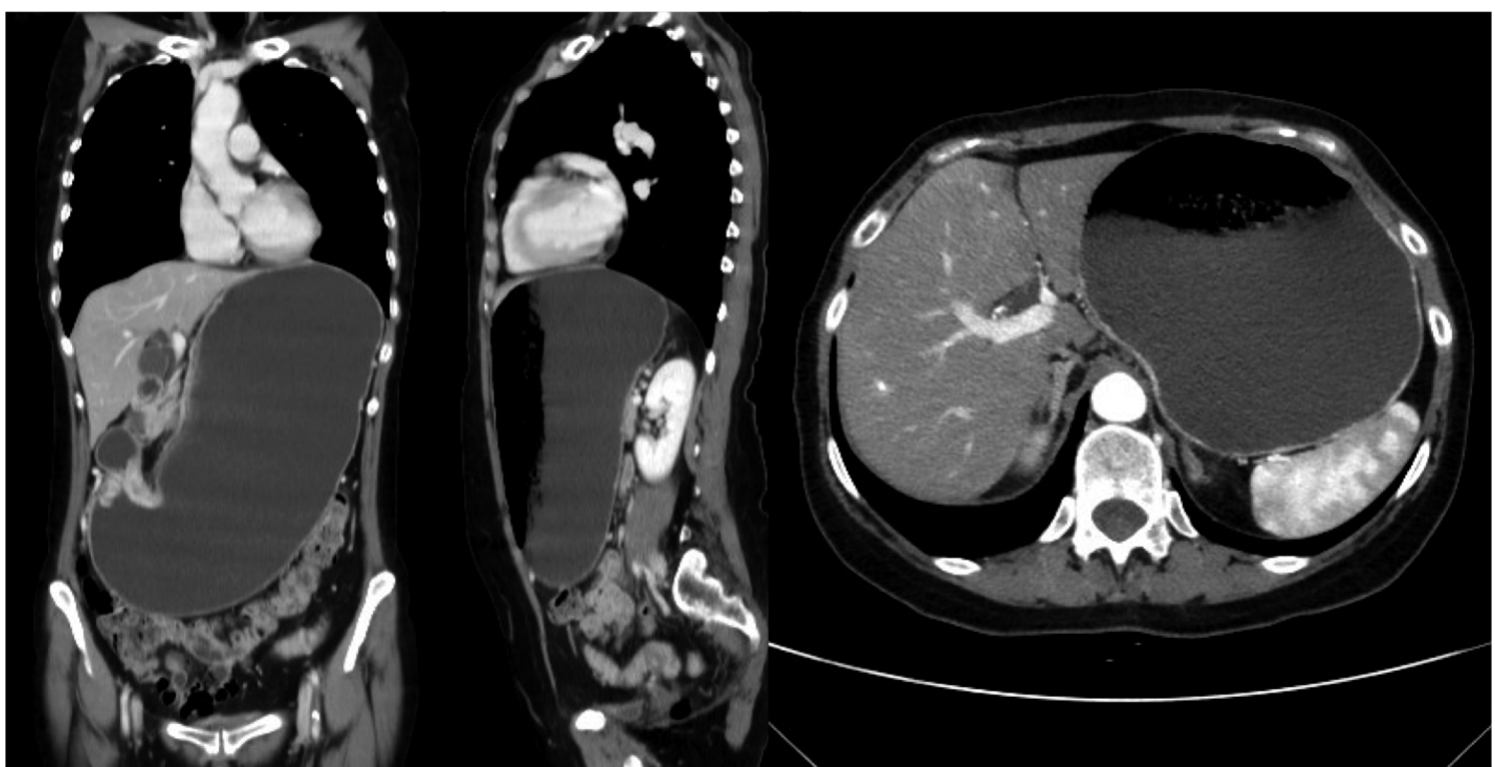

Figura 1. TC de paresia gástrica masiva. 
Figura 2. Imagen macroscópica de linitis plástica y microscópica de células en anillo de sello.

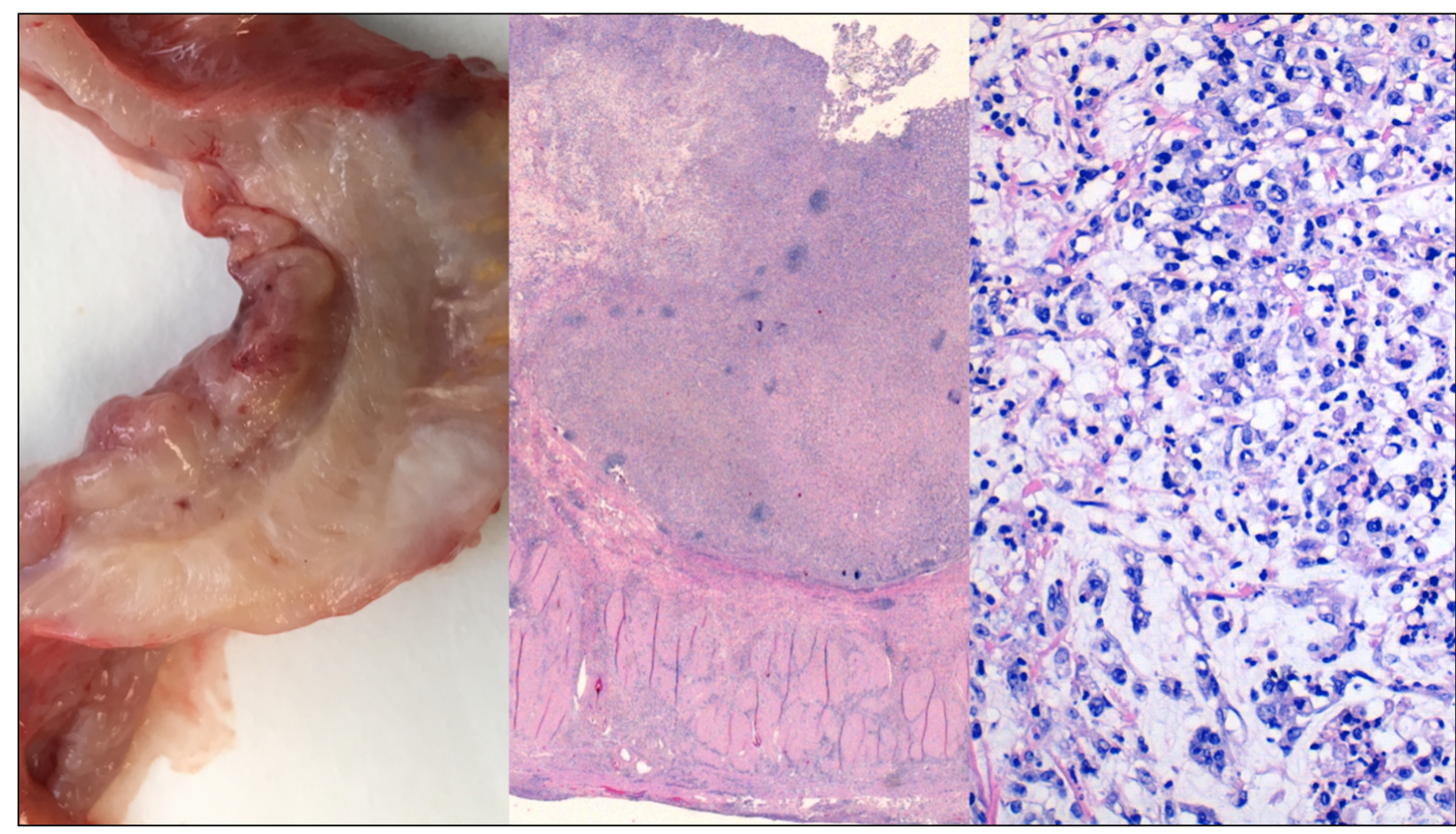

\section{$\underline{\text { Responsabilidades éticas }}$}

Protección de personas y animales. Los autores declaran que para esta investigación no se han realizado experimentos en seres humanos ni en animales.

Confidencialidad de los datos. Los autores declaran que han seguido los protocolos de su centro de trabajo sobre la publicación de datos de pacientes.
Derecho a la privacidad y consentimiento informado. Los autores declaran que en este artículo no aparecen datos de pacientes.

\section{Conflicto de intereses}

Los autores no tienen conflicto de intereses que declarar. 